\title{
RFD
}

\section{A SÚMULA 549 DO STJ: UM ATAQUE À VISÃO CONSTITUCIONAL DO DIREITO CIVIL CONTEMPORÂNEO}

\author{
THE JUDICIAL PRECEDENT RULE 549 OF STJ: AN ATT ACK TO THE \\ CONSTITUCIONAL VIEW OF THE CONTEMPORANY IN CIVIL LAW
}

Lucas de Oliveira Faria ${ }^{1}$

Elcio Trujillo²

Resumo: O artigo em questão visa analisar as razões de aprovação da Súmula 549, em outubro de 2015, pelo Superior Tribunal de Justiça (STJ), Súmula esta que perpetua o entendimento de que é válida a penhora do bem de família do fiador de locação. O escrito pretende explicitar, de forma minuciosa, desde a razão de ser do instituto do bem de família, remetendo à sua origem, até mesmo ao modo como este tipo de instituto se fundamenta no ordenamento constitucional brasileiro, buscando entender se tanto a decisão jurisprudencial do Superior Tribunal de Justiça (STJ), quanto à decisão legislativa de inclusão da exceção de impenhorabilidade do único imóvel do fiador de locação em questão coadunam com a Constituição Federal de 1988 e com o Direito Civil moderno.

Palavras-chave: bem de família, fiador, Constituição, Súmula 549, Direito Civil.

Abstract: The article aims to analyze the reasons for approval the judicial precedent rule 549 on October 2015 by the Superior Justice Court, this document undestand that is valid to pawn the Family asset of the location guarantor. The paper pretend to explain in detail, since the reasons of being of the institute of the Family assets, referring to the origins of the institute, until the way that the institute is based inside the Brazilian constitutional legal order, searching to understand if both the superior justice court decision as the legislative decision of including the exception of the not seizable of the only immobile in the property of the location guarantor, in question, are in converce with the Brazilian's Constitution and with the modern Civil Law.

Key-words: family asset, guarantor, Constitution, judicial precedent rule 549, Civil Law.

\footnotetext{
1 Graduando do $5^{\circ}$ ano de Direito da Faculdade de Ciências Humanas e Sociais (FCHS) - Universidade Estadual Paulista "Júlio de Mesquita Filho" (UNESP) - campus de Franca/SP. Bolsista de Iniciação Científica pelo PIBIC/REITORIA, sob orientação do Prof Dr Elcio Trujillo, no desenvolvimento do projeto intitulado "A Impenhorabilidade do Bem de Família e o Princípio do Mínimo Existencial: A eficácia em conflito"

2 Doutor em Direito da Obrigações pela Faculdade de Ciências Humanas e Sociais, UNESP, campus Franca. Artigo recebido em 19.12.2016 e aprovado para publicação em 19.04.2018.
} 


\section{RFD}

INTRODUÇÃO

O presente artigo busca, em realidade, analisar um problema jurídico que envolve um nítido conflito de direitos e, claro, entre duas noções diversas de sociedade, que buscam utilizar a ciência jurídica de formas diametralmente opostas, como esclarece:

Existem duas sociedades diversas: a dos grupos sociais que guardam consigo o interesse de que o Direito desempenhe tão-somente uma função marginal, como guardião de uma política empresarial, e de outro aquela que demanda justiça para os excluídos. (BARCELONA, 1977, p.27).

Como reflexo da repersonalização do Direito Civil e em busca de uma humanização da execução forçada, a Lei 8.009/90 instituiu a Impenhorabilidade do Bem de Família, prescindindo esta de qualquer declaração de vontade do residente do imóvel, por ser uma proteção conferida diretamente pelo Estado à entidade familiar, com fins de garantir a esta o mínimo necessário para a realização de sua dignidade humana.

Entretanto a proteção ao bem de família não era absoluta, havendo casos, expostos em rol taxativo da lei 8.009/90, em que a penhora seria absolutamente procedente, um destes casos, adicionado pela lei 8.245/91, a Lei de Locações, referia-se ao único imóvel do fiador da locação.

A aprovação da exceção supramencionada causou grande efervescência doutrinária, assim como divergência jurisprudencial, em virtude do questionamento quanto à constitucionalidade do referido dispositivo. Esta divergência chegou às cortes superiores, tanto ao STJ quanto ao Supremo Tribunal Federal (STF). Ambas julgaram que a penhora do imóvel do fiador seria procedente, esta última com divergências entre ministros, e em outubro deste ano de 2015, o Superior Tribunal de Justiça aprovou a Súmula $549^{3}$, admitindo a penhora e buscando resolver a controvérsia.

Deste modo, este escrito buscará analisar a discussão doutrinária e jurisprudencial remetendo desde a origem histórica do instituto do Bem de Família, antes mesmo deste ser introduzido ao direito brasileiro, até sua relação intrínseca e necessária com os princípios esculpidos na Constituição Federal da República, para que se verifique se a admissão da penhora do bem de família do fiador coaduna com a Constituição Federal e, portanto, com o Direito Civil Contemporâneo.

\footnotetext{
${ }^{3}$ Súmula 549: É válida a penhora de bem de família pertencente a fiador de contrato de locação. STJ. $2^{\text {a }}$ Seção. Aprovada em 14.10.2015, DJe 19.10.2015
} 


\section{RFD}

Além disso, verificar-se-á, também, se a atividade do legislador ordinário, principalmente na exceção à Impenhorabilidade adicionada à Lei 8.009/90 pela Lei de Locações, coaduna com os desígnios do legislador constitucional e se, também, não desrespeita frontalmente o espírito do instituto do Bem de Família.

O exercício da pesquisa há de se realizar por meio do método dedutivo, com base em levantamento bibliográfico de obras doutrinárias características do direito civil crítico, como também na análise jurisprudencial, principalmente das Cortes Superiores brasileiras, no intento de descobrir se as linhas interpretativas dos superiores tribunais brasileiros se relacionam de forma harmônica com a Constituição de República.

\section{DA FORMAÇÃO HISTÓRICA DO INSTITUTO DO BEM DE FAMÍLIA}

\subsection{DA ORIGEM DO HOMESTEAD}

Por mais que tenham existido, na Roma Antiga, diversos institutos patrimoniais que buscassem defender a entidade familiar, o instituto do bem de família, de forma juridicamente estruturada, foi originado na República do Texas como sendo uma propriedade agrícola, residencial, separada do patrimônio do proprietário, e que seria uma reserva sagrada para a família.

O termo Homestead, como esclarece Álvaro Villaça Azevedo (1999, p.27), “significa local do lar (home = lar; stead = local), surgindo em defesa da pequena propriedade".

O referido instituto foi criado em virtude dos elevados empréstimos dos especuladores americanos feitos com bancos europeus, que ultrapassaram os limites da realidade, resultando em uma grande crise entre 1837 e 1839.

Os credores, obviamente, buscavam de todas as formas garantir seus proventos, ainda que para isso fosse preciso tomar os bens de seus devedores, entretanto fez-se necessário editar inúmeras leis protegendo os trabalhadores em geral que, inclusive, eram fundamentais para a ocupação do vasto território americano. Assim, após a separação da República do Texas do México, em 1839 foi devidamente promulgada a Lei do Homestead, que defendia de forma expressa a proteção da pequena propriedade, seja rural ou urbana, com critérios pré-estabelecidos de tamanho e valor. 
O instituto do homestead, como se vê, protegia as famílias da República do Texas livrando das execuções judiciais 50 acres de terra rural ou um lote de terreno urbano, compreendendo a habitação e os melhoramentos nos valores estipulados, além dos utensílios. Vê-se que o dispositivo possuía o fim de fixar o homem ao terreno, buscando o desenvolvimento de uma civilização em que os cidadãos tivessem o mínimo necessário para uma vida digna.

Após a fixação do Texas aos Estados Unidos, o instituto foi difundido pelo território americano e criou-se outra espécie de homestead, o homestead federal, preceituado pela Lei Federal de 1862, o famoso Homestead Act. Este previa o direito sobre determinado imóvel devidamente exercido pelo chefe de família que com ela o ocupasse, além da especial publicidade junto ao registro imobiliário, com fins de elucidar aos credores sobre o regime de homestead de certo bem.

No direito americano surgiram, entretanto, duas espécies de homestead, o formal, que necessitava de publicidade registral, e o legal, que prescindia dessa formalização. Verse-á, a seguir, como estas espécies influenciaram o direito brasileiro.

\subsection{DA ABSORÇÃO PELO DIREITO BRASILEIRO: A LEI 8.009/90}

A proteção à residência da família surgiu no direito brasileiro, pela primeira vez, no projeto de Código Civil apresentado por Coelho Rodrigues em 1893, entretanto foi efetivamente positivada apenas no Código Civil de 1916, nos artigos 70 a 73.

O Código Civil de 1916 trazia o bem de família na espécie formal, ou seja, além da simples residência no referido imóvel exigia também a declaração de vontade da sua instituição como bem de família para que, apenas assim, este ficasse isento das execuções forçadas, desde que as dívidas não fossem geradas por impostos referentes ao próprio imóvel.

Em virtude da própria natureza do povo brasileiro, o exacerbado formalismo presente nesta configuração do bem de família acabou por não funcionar muito, fazendo com que sua aplicação fosse bastante rara.

Apesar disso, o Código Civil de 2002 manteve o instituto, preservando seus traços gerais, mas o deslocou da parte geral para a parte do direito de família. 
Entretanto, com intuito de pôr fim ao formalismo supramencionado e conferir maior aplicabilidade ao instituto, o legislador ordinário instituiu o bem de família legal, por meio da Lei 8.009/90.

Araken de Assis (2009, p.17) entende que, no caso do bem de família legal, este não deveria ser chamado por "bem de família", mas "casa de morada", como se vê:

\begin{abstract}
Parece preferível, na hipótese da Lei 8.009/1990, aludir à residência familiar em vez de bem de família, acompanhando o étimo da palavra inglesa. Neste último caso, também se presta oportuna homenagem ao uso vulgar. Na verdade, considerando o objeto da proteção, a terminologia correta é a de "casa de morada", porque a família pode residir em casa alheia ou dividir-se em várias residências. (ASSIS, 2009, 17).
\end{abstract}

A proteção da Lei 8.009/90 é, sem dúvida alguma, muito mais ampla do que a instituída no Código Civil, tanto que esta se estendeu ao obrigado haja ou não constituído família, afinal, como também esclarece Araken (2009, p.18), “essa proteção ao obrigado, mediante a técnica da impenhorabilidade, assegura-lhe o patrimônio mínimo".

Nota-se, portanto, que a Lei 8.009/90 trouxe, para o direito brasileiro, restrições ao exercício da execução, passando a considerar um patrimônio mínimo entendido como absolutamente imprescindível para que o obrigado possa viver dignamente, deste modo analisar-se-á quais os fundamentos sob os quais a referida lei se alicerça, sob o prisma do direito civil à luz da Constituição.

\title{
1.3. DA FUNÇÃO DA LEI $8.009 / 90$ SOB $\quad$ O $\quad$ PRISMA $\quad$ DO DIREITO CIVIL CONTEMPORÂNEO
}

Antes mesmo de entrelaçar a Lei 8.009/90, a qual já foi minimamente esmiuçada nesse artigo, com a concepção contemporânea do Direito Civil, é interessante, por óbvio, explicitar o que se quer dizer com a expressão "Direito Civil Contemporâneo", ou seja, quais são as diferenças desta civilística com aquela clássica, quais são as mudanças e os novos paradigmas.

Durante o século XX houve grande mudança paradigmática no que se refere ao tratamento dado à Carta Constitucional, passando esta a ter status de norma jurídica, deixando de ser um simples documento político, passando a ser um documento normativo. 
Por força desta normatização constitucional, em decorrência lógica, passou a se realizar uma interpretação constitucional dos dispositivos, com a utilização de princípios específicos de natureza constitucional, a partir de novas premissas ideológicas.

Os princípios em questão, princípios constitucionais, ao contrário dos princípios gerais de direito, que possuem natureza supletiva, caracterizam-se como pontos de partida, por serem fundamentos que informam e conformam a lei.

Assim também aconteceu com o direito civil, como elucida Paulo Lôbo (2008, p.38):

\begin{abstract}
Os civilistas, finalmente, descobriram a Constituição. Perceberam que a elevação dos fundamentos do direito civil ao status constitucional foi uma deliberada escolha axiológica da sociedade, indispensável para a consolidação do Estado Democrático e Social de Direito e da consequente promoção da justiça social e da solidariedade, incompatíveis com o modelo liberal anterior de distanciamento jurídico dos interesses privados e de valorização do individualismo. (LÔBO, 2008, p. 38).
\end{abstract}

Deste modo, a ordem jurídica infraconstitucional deve buscar a concretude da organização social exposta na Constituição Federal, no intento de buscar a realização de cânones como a dignidade da pessoa humana, a justiça social e a solidariedade. Ou seja, quando houver matéria objeto de lei infraconstitucional, sua interpretação se fará de acordo com as normas constitucionais aplicáveis, como deve ser feito no caso da Lei 8.009/90, visto que as normas constitucionais hão de se aplicar em qualquer relação jurídica privada.

Como se sabe, a habitação, ou melhor, o "lar" é fundamental para que o indivíduo seja capaz de desenvolver sua personalidade de forma digna sendo, materialmente, um bem incorporado ao conteúdo do mínimo necessário para a existência. Inclusive, como elucida Anderson Schereiber (2002, p.84), outros meios do conhecimento já prenunciam a fulcral importância da casa de morada:

Da mera observação das populações de rua já se conclui que a delimitação de um espaço físico de uso pessoal é pressuposto inafastável da dignidade e da própria personalidade humana. No campo teórico, a psicologia e a filosofia existencialista já, há muito, constataram que ser é necessariamente ser-no-mundo, ser em algum lugar. A própria condição humana depende de uma referência espacial particular, de uma esfera de ocupação determinada, segura e inviolável, em que a personalidade possa desenvolver-se plenamente, dignamente. (SCHEREIBER, 2002, p. 84).

Entendendo o bem de família como instituto fundamental para a realização da dignidade da pessoa humana, vê-se que sua proteção é de suma importância para a 
satisfação dos postulados constitucionais, passando a questionar-se se a exceção inserida pela Lei de Locações não seria responsável por descaracterizar os fundamentos da norma do bem de família.

\title{
2. DOS FUNDAMENTOS DA LEI 8.009/90: A ASCENÇÃO DO MÍNIMO EXISTENCIAL
}

A Lei 8.009/90 deve, antes de tudo, como qualquer outra norma ordinária, ser interpretada de acordo com os ditames da Constituição Cidadã, não devendo ser entendida como uma simples norma que busque proteger um imóvel de execuções.

Sob este prisma, deve-se ressaltar, antes de tudo, que a Constituição Federal de 1988, é responsável por grandes avanços quanto à consagração de direitos fundamentais, mesmo na ordem econômica, cabendo trazer à baila o grande trabalho de Luiz Edson Fachin (2006, p. 01), em sua obra "Estatuto Jurídico do Patrimônio Mínimo", em que o civilista explana:

\begin{abstract}
A pessoa natural, ao lado de atributos inerentes à condição humana, inalienáveis e insuscetíveis de apropriação, pode ser também, à luz do Direito Civil brasileiro contemporâneo, dotada de uma garantia patrimonial que integra sua esfera jurídica. Trata-se de um patrimônio mínimo mensurado consoante parâmetros elementares de uma vida digna e do qual não pode ser expropriada ou desapossada. (FACHIN, 2006, p. 01).
\end{abstract}

Assim sendo, a evolução constitucional brasileira, que atinge diretamente outros ramos do direito, como o Direito Civil, faz com que existam princípios maiores a serem preservados em busca da dignificação da pessoa humana, havendo uma intensificação do caráter humanista do Direito.

Esta evolução é notada em virtude da necessidade de consagração do princípio máximo da Dignidade da Pessoa Humana que só pode ser satisfeito se os cidadãos possuírem condições mínimas de existência e desenvolvimento. Por esta necessidade precípua de haverem fatores mínimos para a existência digna do cidadão é que se denota a total relação entre o mínimo existencial e a instituição do Bem de Família legal, sendo este uma medida para garantir um direito social - a moradia - absolutamente fundamental na realização da dignidade da pessoa humana.

A necessidade supramencionada deve, por óbvio, ter sua garantia realizada pela força do Estado que, inclusive, já consagrou inúmeros direitos sociais como fundamentais, 
como pode-se notar pelo art. $6^{\circ}$ da Carta Magna. Assim sendo, alguns institutos foram relativizados com o intuito de garantir a efetividade dos direitos constitucionais supramencionados, como é o caso da Lei 8.009/90, que protege a moradia contra os anseios do direito de crédito. Trata-se do fenômeno da repersonalização do direito, sendo uma grande mudança de paradigma do ordenamento pós-constitucional, como explana o Professor Gustavo Tepedino, no prefácio da obra de Fachin (2006):

\begin{abstract}
Institutos originariamente destinados à garantia do sistema de crédito e da iniciativa econômica privada são rejuvenescidos, redirecionados à tutela legal de um patrimônio mínimo personalíssimo, este interpretado como aspecto essencial da proteção à dignidade da pessoa humana pretendida pela nova ordem pública constitucional. (TEPEDINO, 2016).
\end{abstract}

Entretanto, por mais que existam direitos fundamentais entendidos como essenciais para a tutela de um mínimo existencial, é necessário desvendar os limiares de aplicabilidade destes direitos, para que uns não se sobreponham sobre outros, afinal não há, de forma alguma, direito absoluto.

Assim sendo, cabe avaliar a aplicabilidade da moradia na busca do patrimônio mínimo.

\title{
2.1. DA MORADIA COMO FATOR DO PATRIMÔNIO MÍNIMO
}

O direito à moradia passou a fazer parte do ordenamento constitucional brasileiro por meio da Emenda Constitucional $n^{\circ} 26$ de 2000, que o incluiu expressamente no conjunto dos direitos fundamentais sociais, expostos no art. $6^{\circ}$ da Constituição.

Como qualquer outro direito fundamental, seu fundamento básico reside no princípio da dignidade da pessoa humana, que preceitua como imprescindível a "compensação das desigualdades fáticas de modo a assegurar a proteção da pessoa (de qualquer pessoa) contra as necessidades de ordem material, garantindo uma existência digna". (SARLET, 2007, p.03), ou seja, a garantia de um mínimo existencial.

Alguns doutrinadores acabam por inserir o direito à moradia como direito de subsistência, sendo entendido como necessário à proteção mínima da própria vida, sustentando-se inclusive sua inclusão no rol dos direitos à personalidade.

A partir do conceito de que a moradia é direito fundamental e de incomensurável importância na esfera garantidora do patrimônio mínimo, imprescindível à realização da 
dignidade da pessoa humana, cabe esclarecer qual o papel do Estado no que se refere à produção da eficácia do direito em questão, afinal o avanço constitucional brasileiro, apesar de nítido, enfrenta grande obstáculo no plano fático, sendo intenso o conflito entre positivação e efetivação, como elucida Fachin (2006):

O grande desafio é superar um velho problema, a clivagem abissal entre a proclamação discursiva das boas intenções e a efetivação da experiência. Esse dilema, simploriamente reduzido ao fosso entre a teoria e a prática, convive diuturnamente na educação jurídica. (FACHIN, 2006)

Em busca da efetivação dos postulados constitucionais, o Estado deve entender o direito fundamental à moradia como um direito fundamental subjetivo de duas dimensões, sendo um direito obrigacional com uma dimensão positiva e outra negativa.

A dimensão positiva do direito à moradia realiza-se por meio das políticas públicas estatais com o fim de diminuir o déficit habitacional da nação, em contrapartida, a dimensão negativa, que é exatamente a que nos interessa neste estudo, consiste na proteção do bem jurídico fundamental tutelado contra todas as ingerências indevidas, devendo todo ato capaz de ofender o direito à moradia ser repudiado em juízo.

Ao direito de moradia, em sua condição de direito de defesa, pode-se aplicar a teoria tridimensional de Robert Alexy, que divide a dimensão negativa em três tipos de direitos:

Na sua condição de direito (subjetivo) negativo ou de defesa, também ao direito à moradia é aplicável a lição de Robert Alexy, especialmente quando demonstra que a dimensão negativa abrange: a) direitos ao não-impedimento de ações; b) direitos à não-afetação de propriedades ou situações (em suma, não-afetação de determinados bens jurídicos); c) direitos à não-eliminação de posições jurídicas (SARLET, 2007, p. .09)

Por essa concepção, entende-se que a dimensão negativa dos direitos fundamentais corresponde à necessidade de se proteger o direito que já é garantido e não necessariamente de promover políticas para que ele passe a ser oferecido, ou seja, a dimensão negativa de um direito fundamental significa que o Estado deve agir para que o direito não seja furtado de seu detentor, obviamente que há exceções, nos casos de conflito com outro direito fundamental de maior importância, entretanto, caso não haja outro direito fundamental de maior relevância, deve o Estado assegurar sua proteção.

A atuação imposta pela dimensão negativa é, também, um indispensável modo de tutelar a dimensão positiva, como elucida Sarlet, "de nada adiantará assegurar 
(positivamente) o acesso a uma moradia digna, se esta moradia não estiver protegida (negativamente) contra ações do Estado e de terceiros". (2007, p.10)

Assim, é exatamente em virtude da dimensão negativa dos direitos fundamentais prestacionais, que são gerados poderes subjetivos negativos, para que se viabilize a impugnação de atos contrários à sua realização, como no caso do direito à moradia quando da proteção da propriedade que serve de moradia contra a penhora em execuções de variadas espécies. (SARLET, 2009, p.282)

Nota-se, portanto, que o direito à moradia é direito fundamental que possui também dimensão negativa, sendo assim garantido pela Constituição Federal, entretanto há questionamentos quanto ao fato da norma contida no art. $6^{\circ}$ da $\mathrm{CF}$ não possuir eficácia plena. Como se sabe, a teoria constitucional reiterada nos manuais de direito constitucional divide as normas constitucionais de acordo com seu grau de eficácia, como demonstra o Professor André Ramos Tavares (2002, p. 82-83):

\begin{abstract}
São normas constitucionais de eficácia plena aquelas que têm aplicabilidade imediata, e portanto independem de legislação posterior para sua plena execução. Desde a entrada em vigor da Constituição, produzem seus efeitos essenciais, ou apresentam a possibilidade de produzi-los. Consideram-se normas constitucionais de eficácia contida aquelas que têm igualmente aplicabilidade imediata, irrestrita, comparando-se, nesse ponto, às normas de eficácia plena, mas delas se distanciando por admitirem a redução de seu alcance (constitucional) pela atividade do legislador infraconstitucional. (...)

Por fim, as normas constitucionais de eficácia limitada são aquelas que dependem de regulamentação futura, na qual o legislador infraconstitucional vai dar eficácia à vontade do constituinte. (TAVARES, 2002, p. 82-83)
\end{abstract}

Todavia, com base na busca da efetivação do mínimo existencial e até mesmo na busca da eficácia dos direitos sociais da Constituição Federal Brasileira, deve-se partir do pressuposto que os direitos fundamentais, de acordo com o artigo $5^{\circ}$, parágrafo $1^{\circ}$ da $\mathrm{CF}$, são diretamente aplicáveis. Deste modo, os direitos fundamentais desencadeiam efeitos diretos e não podem ser condicionados à prévia regulação legal.

Inclusive, no caso dos direitos de defesa, em virtude da dimensão negativa, nada impede que tais conceitos tenham seu conteúdo definido pela via de intervenção judicial, não significando que o direito à moradia seja absoluto, no sentido de completamente imune à restrição.

Deste modo, a proteção envolta no Bem de Família deve ser entendida como uma medida para assegurar a feição de direito fundamental com dimensão defensiva do direito à 
moradia e, assim, em caso de ofensa direta ao instituto do bem de família e ao mínimo existencial, poderá o próprio judiciário resolver a controvérsia, buscando assegurar, como preceitua Alexy, o direito de não-afetação da moradia.

Após a conclusão supratranscrita é que se nota um certo conflito entre o entendimento do Superior Tribunal de Justiça na aprovação da Súmula 549, que admite a exceção de impenhorabilidade do bem de família do fiador de locação, e a Constituição Federal, que busca a realização da dignidade da pessoa humana e o mínimo existencial.

\section{DO INÍCIO DA CONTROVÉRSIA QUANTO AO BEM DE FAMÍLIA DO FIADOR ATÉ A APROVAÇÃO DA SÚMULA 549: DO DESRESPEITO AO DIREITO À MORADIA}

Por força dos argumentos acima e da ideia central de que uma das funções do Estado, decorrente da Carta Constitucional, é oferecer as condições necessárias para a garantia das condições mínimas para a existência digna do cidadão, é de se afirmar que a exceção de impenhorabilidade constante no inciso VII do art. $3^{\circ}$ da Lei 8.009/90 é diametralmente oposta aos ditames da Constituição Federal, como se vê:

Art. $3^{\circ}$ A impenhorabilidade é oponível em qualquer processo de execução civil, fiscal, previdenciária, trabalhista ou de outra natureza, salvo se movido:

VII - por obrigação decorrente de fiança concedida em contrato de locação. (BRASIL, 1990).

O inciso VII mostra a nítida incongruência do legislador quanto à ponderação dos direitos em jogo quando da proteção do referido imóvel, visto que, ao privilegiar o direito de crédito imobiliário em contraposição ao direito de moradia, fere diretamente o próprio objetivo constitucional sob o qual se interpreta a referida lei, ou seja, a garantia do mínimo existencial.

É de se perceber que o legislador ordinário feriu totalmente o espírito da Lei 8.009/90 e estabeleceu exceção de aplicabilidade da lei que demonstra grande retrocesso se comparada ao total avanço do próprio Direito Civil quanto ao entendimento do patrimônio.

Como já dito anteriormente, o Direito Civil, após o advento da Constituição Cidadã, sofreu uma intensa mudança de paradigmas havendo certa inversão de prioridades geradas pela intensificação do caráter social do ordenamento, assim sendo, não faz sentido um postulado que venha a sobrepor a garantia creditícia ao direito de moradia, como já elucida 
Fachin (2006, P.173): “Entre a garantia creditícia e a dignidade pessoal, opta-se por esta que deve propiciar a manutenção dos meios indispensáveis à sobrevivência.".

Cabe reiterar que não se busca, de modo algum, asseverar que o direito à moradia é absoluto, entretanto não deve ser admissível que em uma ponderação entre um direito de crédito e um direito fundamental, o direito de crédito seja privilegiado, isto seria desconsiderar a função social da propriedade que, neste caso, teria o caráter especulativo sobrepujado à própria função habitacional, o que é plenamente incoerente com o ordenamento constitucional.

Entretanto, a divergência não se fez unicamente após a aprovação legislativa, em razão do intenso questionamento doutrinário quanto à patente inconstitucionalidade do dispositivo, houve também grande contradição jurisprudencial acerca da possibilidade de aplicação da referida exceção de impenhorabilidade, tanto que vários tribunais não a aplicaram em virtude de a considerarem inconstitucional. Exatamente em razão disto, a divergência chegou até o arbítrio das cortes superiores brasileiras, ocorrendo, inclusive, intensa discussão em plenário do Supremo Tribunal Federal sobre o tema.

O Judiciário Brasileiro, em suas mais altas cortes, anteriormente no Supremo Tribunal Federal $(\mathrm{STF})^{4}$ e mais recentemente no Superior Tribunal de Justiça $(\mathrm{STJ})^{5}$, nas indagações que teve quanto à constitucionalidade do inciso VII do art $3^{\circ}$ da Lei do Bem de Família, desenvolveu interpretação que não coaduna com a Constituição Federal ao entender, por argumentos não muito razoáveis, que a referida exceção não ofendia o direito à moradia e que era necessário preservar o bom andamento do mercado imobiliário, principalmente pelo fato do direito à moradia não ser uma norma de eficácia plena, já que necessita de regulamentação.

Pois bem, a eficácia do art $6^{\circ}$ da Constituição Federal, como já se elucidou, deve ser analisada de forma bastante minuciosa, em razão da dupla dimensão do direito à moradia. Em sua dimensão obrigacional positiva, é lógico que a eficácia não é plena, visto que o Estado, por meio de ato do legislador, ainda precisa regulamentar os meios pelos quais proporcionará a realização do direito à moradia, entretanto na dimensão negativa, é patente

\footnotetext{
${ }^{4}$ Brasil. Supremo Tribunal Federal. Brasília. Recurso Extraordinário n 407.688-8/SP. Ministro Relator Cézar Peluso. Julgado em 8 de fevereiro de 2006. Publicado no Diário da Justiça de 6 de Outubro de 2006. Disponível em: http://www.stf.gov.br. Acesso em 15/10/2015

${ }^{5}$ Brasil. Superior Tribunal de Justiça. Brasília. Recurso Especial no 1.363.368/MS. Ministro Relator Luis Felipe Salomão. Julgado em 12 de novembro de 2014. Publicado no Diário da Justiça de 21 de novembro de 2014. Disponível em: http://www.stj.jus.br. Acesso em 15/10/2015
} 
que a aplicabilidade da norma é imediata e inquestionável. Ora, se a moradia está assegurada no caso concreto, como pode o Estado furtar-se de protegê-la, ainda que por via judicial, sob o argumento de que não há eficácia na lei? Neste caso, não estaria o próprio Estado deixando de fazer real a eficácia?

Isto posto, nota-se que ocorre exacerbada falha legislativa no que se refere à introdução do inciso VII do art $3^{\circ}$ da Lei 8.009/90 e, também, existe grave erro hermenêutico nos entendimentos das maiores cortes do país quanto à constitucionalidade do referido inciso, não podendo se permitir que a Lei do Bem de Família tenha dispositivo que atenta diretamente contra a busca dos fins que tentou o legislador ordinário garantir e que, ainda, afronta diretamente os anseios do legislador constitucional. Não se deve aceitar que o Judiciário Brasileiro reafirme uma postura conservadora e patrimonialista de ver o Direito, postura que não condiz mais com a evolução constitucional conferida ao ordenamento, não podendo desistir de perpetuar os anseios que constituem a criação e evolução de um Estado Social, que não mais se faz pela desenfreada evolução do individual, mas na melhoria de possibilidades para desenvolvimento do coletivo.

Assim, há de se buscar uma interpretação constitucional da norma que coadune com os propósitos de justiça social e redução da desigualdade, que só poderão ser garantidos se o Mínimo Existencial for condição inabalável de todos os cidadãos, afinal:

As exigências de uma realidade socioeconômica devem ser coerentes, a fim de não reduzir à sociedade ao mercado, mas de reconhecê-la como uma constância equilibrada de valores que, informados pela solidariedade constitucional, possam apresentar melhores condições de vida para todos". (PINHEIRO; ISAGUIRRE. 2008. p.164)

Com o viés de elucidar a total incongruência legislativa e judiciária, agora reafirmada pela aprovação da Súmula 549 pelo STJ, e buscar, timidamente, mostrar o modo correto de saná-la, analisar-se-á minuciosamente os defeitos e incongruências do pensamento adotado, para que o dispositivo seja interpretado de forma que coadune com a Constituição Federal e seus objetivos.

\section{A APROVAÇÃO DA SÚMULA 549: DOS VÍCIOS E CONTRADIÇÕES}

Sabe-se que a norma 8.009/90 possui sério vício no que se refere à exceção de sua aplicação quanto ao bem de família do fiador da locação, sendo este vício tanto na prática 
legislativa, que por meio da Lei de Locações incluiu esta exceção na norma do bem de família, quanto pela atividade judiciária, que não afastou o referido inciso em razão de sua exacerbada inconstitucionalidade, buscando resolver a controvérsia com a aprovação da Súmula 549.

Como já exaustivamente explanado, a referida exceção atenta contra a Constituição, em razão de ser diametralmente oposta aos objetivos traçados pela Carta Constitucional, como o direito à Moradia, o direito ao Mínimo Existencial, ambos ancorados no princípio fundante da Dignidade da Pessoa Humana. Todavia, como se não bastasse, há inúmeros outros vícios presentes na exceção de impenhorabilidade do bem de família do fiador, que deflagram o quão a referida norma é desconexa dos fundamentos do ordenamento pátrio, que hão de ser explicitados a seguir.

Inicia-se o questionamento sobre a própria natureza da fiança que é contrato unilateral, visto que só gera obrigações ao fiador; solene, depende de forma escrita imposta por lei; gratuito, pois o fiador nada recebe em troca; benéfico, pois não admite interpretação extensiva, apenas restritiva; personalíssimo e, claro, acessório e subsidiário.

Assim sendo, a fiança é totalmente dependente do contrato principal, havendo tanto no contrato principal quanto na fiança a mesma razão fundamental devendo-se, portanto, aplicar o mesmo direito.

Por assim ser, é notado um imenso desrespeito ao princípio da isonomia, afinal o fiador e o devedor principal são tratados de forma totalmente distinta, enquanto o afiançado inadimplente é beneficiado pela impenhorabilidade, o fiador tem seu benefício subtraído.

Nota-se, portanto, que o fiador de locação acaba por ser entendido como responsável pela dívida, independentemente do afiançado, fazendo com que, em realidade, seja encarado como verdadeiro avalista, afinal de contas, nos contratos locatícios, em sua maioria esmagadora, há renúncia ao benefício de ordem, sendo o fiador diretamente responsável pela obrigação do locatário.

Percebe-se, portanto, que o grande raciocínio isonômico de tratar igualmente os iguais e desigualmente os desiguais para, assim, promover a igualdade material é utilizado de forma totalmente errônea, já que na situação em pauta dois iguais são tratados desigualmente. 
Inclusive, alguns tribunais brasileiros, ainda quando a questão não havia sido apreciada pelas cortes superiores, já haviam se atentado para este patente desrespeito à isonomia, que acabava por gerar situação esdrúxula, em que o fiador, mesmo após ter perdido seu imóvel, não teria êxito em caso de ação de regresso, como se vê:

\begin{abstract}
Nesse aspecto, alguns acórdãos, proferidos pelos tribunais, acabaram por afastar a penhorabilidade com fundamento também na ofensa ao princípio da igualdade, previsto no caput e inciso I, do art $5^{\circ}$ da Constituição da República. De fato, a desigualdade surge quando da hipótese de execução movida pelo fiador subrogado, pois este não poderá penhorar o imóvel de residência do inquilino, devedor originário dos débitos da locação. (PINHEIRO; ISAGUIRRE, 2008, p.137)
\end{abstract}

Como se sabe a igualdade é um postulado de racionalidade prática, para todos os indivíduos de características iguais se aplica o mesmo dispositivo, deste modo, para que ocorresse o tratamento diferenciado entre fiador e afiançado dever-se-ia considerar como preponderante a natureza de garante, entretanto, se assim se fizesse, estar-se-ia considerando que em um embate entre a natureza de garante e a moradia, esta última não teria valor prevalente, o que é absolutamente contrário ao ordenamento constitucional.

O eminente ministro Eros Grau, no julgamento pelo plenário do Supremo Tribunal Federal de Recurso Extraordinário que versava sobre esta questão, expôs, em seu voto vencido, a evidente afronta à isonomia, ao elucidar:

\footnotetext{
Se o benefício da impenhorabilidade viesse a ser ressalvado quanto a fiador em uma relação de locação, poderíamos chegar a uma situação absurda: o locatário que não cumprisse a obrigação de pagar aluguéis, com o fito de poupar para pagar prestações devidas em razão de aquisição de casa própria, gozaria da proteção da impenhorabilidade. Gozaria dela mesmo em caso de execução procedida pelo fiador cujo imóvel resultou penhorado por conta do inadimplemento das suas obrigações, dele, locatário. (BRASIL, SUPREMO, 2006. p.889)
}

Ora, que o direito em questão não é absoluto já se sabe, este deve ser ponderado para menos em caso de conflitos com outros direitos fundamentais que sejam mais preponderantes, como se vê no caso das outras exceções à impenhorabilidade, ou seja, nas situações, por exemplo, de obrigação tributária, daquela decorrente de ato ilícito, do crédito decorrente de natureza alimentar. Vê-se que o direito tutelado pela exceção aqui questionada é, explicitamente, o direito de crédito, um direito muito inferior ao direito de moradia, ao mínimo existencial, é isto que é inadmissível. Não é perturbadora a 
relativização da moradia, é perturbadora a relativização da moradia em prol do mercado, da acumulação, como se vê:

Tenho me manifestado, porém, em sentido contrário mesmo antes da EC n. 26, ou seja, tenho defendido a ideia de que, em se tratando de bem imóvel, sendo o mesmo residência da família, ao fiador se estende a impenhorabilidade do único imóvel que sirva de residência familiar tendo em vista o fim social da Lei 8.009/90 e a afronta do art. 82 da Lei 8.245 ao valor fundamental de preservação da dignidade humana (art $1^{\circ}$, inc III da CF), ao princípio da isonomia (art $5^{\circ} \mathrm{da} C F$ ). (ALBERTON, 2003, p.117-118).

Discute-se aqui, portanto, uma exceção à impenhorabilidade do bem de família que busca, única e exclusivamente, atender a um interesse mercadológico e manter funcionando de forma pacífica as engrenagens da especulação locatícia, ainda que, para isso, seja necessário ferir de morte princípios constitucionais de grande relevância, como a isonomia, a moradia e até mesmo a dignidade da pessoa humana, como já ressaltado pelo Ministro Eros Grau (2006.p. 890) “A minha discordância do voto de Vossa Excelência é que não estou me apegando à lógica do mercado no meu voto, mas, sim, ao que diz a Constituição."

Ademais, deve-se questionar também a própria natureza do contrato de locação, buscando classificá-lo como um contrato paritário ou um contrato de adesão.

Os contratos paritários e de adesão diferenciam-se, basicamente, pelo fato de, nos primeiros, ocorrer a livre discussão entre as partes sobre as condições da avença, por estas estarem em situação de igualdade. Já no contrato de adesão, as partes não discutem cláusulas, a avença já é pronta e indiscutível, em razão da necessidade de contratar, e, também, de uma parte estar, necessariamente, em posição de desvantagem se comparada à outra.

Os contratos de locação, de forma absolutamente majoritária, são celebrados por administradores de imóveis que representam os locadores, estas redigem as cláusulas de forma prévia e unilateral e apresentam uma proposta que ou é aderida integralmente ou recusada integralmente, ou seja, não existe uma fase pré-negocial.

Deste modo, no momento da adesão ao contrato não existe explanação convincente ao fiador sobre a renúncia ao benefício de ordem, ou seja, não se esclarece a real situação, como menciona João Hora Neto (2007): 
Celebram o instrumento (...) sem que o contratante mais forte lhes advirta previamente, elucidando, por exemplo, sobre o real significado da renúncia ao benefício de ordem, em sede de fiança, e perante o atual posicionamento jurisprudencial dominante, qual seja: que se o inquilino não adimplir com sua obrigação (pagar os aluguéis), o locador executará o fiador (devedor solidário, em face da renúncia ao benefício de ordem), e o fiador perderá seu único imóvel residencial (bem de família), para quitar uma dívida que não lhe pertence, sendo que o fiador, depois, ao fazer a ação regressiva contra o inquilino, este nada pagará, posto que sua casa de morar acha-se protegida pelo manto da impenhorabilidade. (NETO, 2007)

É nítida a natureza de contrato de adesão que circunda o contrato locatício, sob a qual deve-se aplicar, por ser contrato de consumo, em que um indivíduo, por meio de uma prestação pecuniária, adquire o direito de utilizar de um imóvel por determinado tempo, o Código de Defesa do Consumidor. Assim sendo, é imprescindível que o contrato de locação seja regido pela boa-fé objetiva, transparência e confiança, consagrando a ideia de que o fiador deve ser expressamente informado sob as consequências de sua fiança. Isto claramente não é realizado, fazendo com que a penhora do bem do fiador seja ainda mais absurda.

Todavia, ousamos estender nosso raciocínio para um pouco mais além, aplicando-o em uma idealização negocial em que o fiador seria devidamente informado de seus riscos, ainda nesta situação discorda-se da procedência da penhora do bem de família, como se verá a seguir.

A nova ordem jurídica brasileira se faz com um certo grau de dirigismo estatal, sendo impostos sérios limites à autonomia privada, ainda mais no caso de direitos fundamentais. Deste modo, por haver conexão indissolúvel com a dignidade da pessoa humana e o mínimo existencial, Ingo Wolfgang Sarlet ressalta a impossibilidade de um indivíduo se abster de sua própria moradia, ainda que seja devidamente informado sobre o que está fazendo, como também afirma o ministro Carlos Ayres Britto:

\begin{abstract}
A partir dessas qualificações constitucionais, sobretudo aquela que faz da moradia uma necessidade essencial, vital básica do trabalhador e de sua família, entendo que esse direito à moradia se torna indisponível, é não-potestativo, não pode sofrer penhora por efeito de um contrato de fiação. Ele não pode, mediante um contrato de fiação, decair. (BRASIL, SUPREMO, 2006, p. 901).
\end{abstract}

Ou seja, debruçando-se restritivamente sobre o caso do contrato de fiança, é absolutamente inconcebível que o indivíduo possa se abster de seu próprio bem de família, de sua casa de morada, o bem indispensável para sua existência digna e de sua família, para 
assegurar um direito de crédito de terceiro, fazendo-se necessário que se faça a proteção do indivíduo contra ele mesmo.

Um argumento bastante utilizado pelos favoráveis a penhora do bem do fiador nas cortes superiores brasileiras, o Supremo Tribunal Federal e o Superior Tribunal de Justiça, trata da necessidade da penhora do bem do fiador para, ao contrário do que se defende, ampliar a garantia de moradia.

O Ministro Cezar Peluso, como relator do Recurso Extraordinário que se discutiu acima, responsável por angariar 7 votos contra os outros 3 que acompanharam o Ministro Eros Grau, defendia que a garantia da fiança, ainda que no caso de bem de família, deveria ser mantida para o bom funcionamento do mercado imobiliário, pois isto seria, na verdade, um incentivo ao direito de moradia, como se vê:

Por isso foi que me referi especificamente à disposição da Constituição portuguesa, por ser muito exemplificativa e até didática. Ela diz que o Estado pode, para a tutela do direito de moradia, tomar uma medida de incentivo à moradia arrendada, que compreende os casos de locação. (BRASIL, SUPREMO, 2006, p.895)

Entretanto, a interpretação exposta é bastante problemática, afinal não é muito saudável que tanto as cortes superiores da nação quanto o próprio legislativo optem por uma garantia que recaia no meio mais gravoso possível, ou seja, a afetação da moradia do fiador, quando, em realidade, existem outras ferramentas capazes de resolver o problema.

Inclusive, o argumento frequentemente utilizado, principalmente pelas Cortes Superiores, de que não existe outro meio capaz de garantir o crédito é evidentemente falacioso, já que outras alternativas não foram nem mesmo analisadas.

Aliás, há, inclusive, previsões legais na própria lei de locações que, se trabalhadas de forma mais efusiva, podem proporcionar maior garantia ao detentor do crédito locatício sem, para isso, ferir de morte os princípios da república, como por exemplo o seguro de fiança locatícia, previsto no artigo 37 do inciso III da Lei de Locações, como se vê:

Entendo que o Governo deve intervir no mercado, via Executivo e via Legislativo, no sentido de reestruturar a garantia locatícia denominada seguro de fiança locatícia, prevista no artigo 37 inciso III da Lei 8.245/91, hoje praticamente sem uso devido a uma regulamentação legal débil, lacunosa, que praticamente não funciona em razão da usura do sistema bancário ou securitário, e que impõe condições abusivas em detrimento dos interesses do locador, além de afrontar à própria Lei do Inquilinato, repleta de regras cogentes e imperativas. (NETO, 2007, p.50) 
Ora, se a solução adotada pelo Estado, seja pela esfera judiciária ou legislativa, é a de estimular a locação para garantir a moradia, que isto seja feito por meio do dirigismo estatal para que se controle a exacerbada usura bancária sob o serviço do seguro fiança. Esta seria sim uma prestação do Estado para que a esfera defensiva do direito de moradia de um fiador que possui um único imóvel onde pode abrigar sua família não fosse totalmente dilacerada, significando a morte dos princípios do Estado Constitucional Brasileiro.

Além disso, entende-se que, independente da opção que melhor favoreça o mercado de locações, é impensável que esta justifique o sacrifício da moradia do fiador em razão da patente necessidade de prevalência da dignidade da pessoa humana e do mínimo existencial que sempre devem ser, em primeiro plano, auferidos na situação concreta, da pessoa diretamente atingida, não podendo ser dissolvida no contexto coletivo, ainda mais quando referida a uma possível e sequer demonstrada falta de acesso à moradia digna por parte de outra pessoa. Não se deve, de modo algum, se permitir que a percepção dos direitos sociais na esfera coletiva acabe por ferir de morte a esfera individual, como já se preceitua na boa doutrina:

O que há de ser devidamente enfatizado, é a circunstância de que direitos humanos e fundamentais, sejam eles civis e políticos, sejam eles sociais, econômicos e culturais (assim como os ambientais em certo sentido), são sempre direitos referidos, em primeira linha, à pessoa individualmente considerada, e é a pessoa (cuja dignidade é pessoal, individual, embora socialmente vinculada e responsiva) o seu titular por excelência. Possivelmente, o exemplo mais contundente desta titularidade individual dos direitos sociais esteja atualmente associado ao assim designado direito (e garantia) ao mínimo existencial, por sua vez, fundado essencialmente na conjugação entre o direito à vida e o princípio da dignidade da pessoa humana, e que, precisamente por esta fundamentação, não pode ter sua titularidade individual afastada, por dissolvida numa dimensão coletiva (...) os direitos sociais encontram seu fundamento e sua função na proteção das pessoas no contexto de sua situação concreta na sociedade. (SARLET, 2009, p. 216)

Além de todo o já exposto que explicita de variada os inúmeros vícios da interpretação constitucional adotada quanto à exceção de impenhorabilidade do imóvel do fiador de locação, ainda se ignora totalmente um dos grandes objetivos da Lei 8.009/90, qual seja, a tutela da entidade familiar, mantendo-a em seu núcleo habitacional, tutela esta exigida pelo art. 226 da Constituição da República, ou seja, é absolutamente necessário que 


\section{RFD}

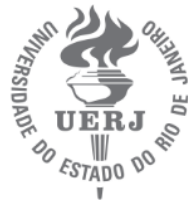

todos os argumentos elucidados neste capítulo sejam levados em conta, principalmente por formarem todos um pensamento sólido, coerente e contemplado pela Constituição, para que se busque uma interpretação que abarque de forma muito mais eficaz os fins da República Brasileira, ao contrário do que se faz com a Súmula 549 do Superior Tribunal de Justiça, que não deixa de ferir a dignidade da pessoa humana em prol das engrenagens do mercado especulativo imobiliário.

\section{CONCLUSÃO}

O Bem de Família, juridicamente concebido na República do Texas, chegou ao Brasil de forma tímida, banhado por excesso de formalismo, não obtendo muito êxito em seu uso exatamente por demandar registro pelo instituidor, atravancando, assim, sua aplicabilidade. Entretanto, com o advento da Lei 8.009/90, o referido instituto teve seu reconhecimento ampliado pelo Estado, passando a ser desnecessária a instituição pelo morador, visto que o próprio Estado conferia a proteção do bem por força de lei, bastando, tão só, a habitação.

A Lei 8.009/90, positivada dois anos após a Constituição Federal, é um dos exemplos do fenômeno da repersonalização do Direito Civil, fenômeno este que busca reconhecer as garantias fundamentais consagradas pela Constituição Federal e aplicá-las ao Direito Civil, tão marcado pela autonomia privada e exacerbada liberdade contratual.

A norma, como se percebeu no decorrer dos estudos, busca entender o bem de família, bem único em que reside a entidade familiar ou ainda o indivíduo solteiro, como um imóvel a ser protegido contra execuções forçadas, buscando, assim, proteger a entidade familiar ou o morador individual contra a possibilidade deste perder seu teto de morada e, por corolário, ter sua dignidade totalmente violada. Afinal, a moradia, direito fundamental constitucionalmente garantido pela $\mathrm{CF} / 88$, constitui o núcleo dos direitos imprescindíveis para a consagração da dignidade da pessoa humana, por ser fator do mínimo existencial, ou seja, indispensável para que um indivíduo tenha uma vida digna e possa desenvolver-se socialmente.

Deste modo, a norma instituidora do bem de família só haveria de ser eficaz se fosse capaz de cumprir os intentos para os quais foi criada, ou seja, defender o bem da entidade familiar ou do morador individual de execuções forçadas, só podendo esta proteção ser 


\section{RFD}

relativizada caso houvesse um interesse superior ao mínimo existencial ou que com este pudesse ser ponderado.

A atividade do legislador ordinário, que por meio da edição da Lei de Locações Imobiliárias, adicionou o referido inciso na Lei do Bem de Família, atinge diretamente o espírito do instituto do bem de família, pois insere exceção de conteúdo jurídico totalmente vulgar ao ser balanceado com o que se defende na instituição do bem de família. Ora, pois, não é de se entender razoável, no ordenamento jurídico constitucional brasileiro, que se possa sobrepor um direito de crédito contratual sobre o mínimo existencial e a dignidade da pessoa humana.

Todavia, o maior percalço não é apenas a atividade legislativa que acaba por atender um interesse puro de mercado. Os estudos empreendidos notaram, também, o que se entende como um vício de interpretação nas cortes superiores do país no que se refere à questão suscitada, vício este reforçado pelo Superior Tribunal de Justiça na edição da Súmula 549, que busca de forma errônea resolver a controvérsia.

A partir da leitura dos votos do Supremo Tribunal Federal em Recurso Extraordinário que buscou resolver a questão da impenhorabilidade do bem de família do fiador, foi possível notar que a argumentação dos votos vencedores, principalmente na corte do Supremo Tribunal Federal, acaba por interpretar a Constituição de forma errônea com nítidos fins de consagrar a boa manutenção das engrenagens do mercado imobiliário, ainda que, para isso, seja necessário sacrificar princípios constitucionais de grande relevância.

É de se lamentar que, não só a questão escandalosamente relevante da supremacia da dignidade da pessoa humana e da necessidade de proteção do mínimo existencial, inúmeros pontos de nítido desrespeito ao ordenamento jurídico foram ignorados, como a questão da ofensa à isonomia entre fiador e locatário, o nítido caráter de contrato de adesão da locação, além do desarrazoado argumento utilizado de que, em realidade, o estimulo à locação garantido por esta exceção à impenhorabilidade é alternativa única capaz de até mesmo aumentar a moradia e não feri-la, entendimento totalmente descompromissado com a realidade e que analisa a questão de violação dos direitos fundamentais de dimensão negativa em uma esfera coletiva e não individual, o que não é admissível.

Vê-se, portanto, que a aprovação da Súmula 549 pelo Superior Tribunal de Justiça mostra que apesar de inúmeros avanços na positivação de direitos fundamentais em nossa Constituição, que não possui grandes déficits de normatividade neste ramo, infelizmente, a 
prática jurisdicional apresenta um déficit de aplicabilidade. É lamentável, portanto, que tanto o legislativo brasileiro quanto as cortes superiores, nesta questão em específico, tenham privilegiado os interesses de mercado, ainda que para isso tenha sido necessário subverter os ditames da Constituição Federal.

É preciso, antes de tudo, que, principalmente aqueles responsáveis pela produção do direito crítico, não deixem de fazer seu papel na busca da realização de um direito constitucionalmente justo, que faça aplicáveis as normatizações que já foram conquistadas, pois não se pode permitir que existam vícios como os aqui explanados, vícios estes devidamente sumulados, que cheguem a fazer prevalecer a ordem econômica sob a ordem constitucional.

Por mais vultuosos que sejam os percalços para que os anseios de uma interpretação constitucional do direito, interpretação esta em que seja inquestionável a ideia de que não é admissível que um indivíduo perca sua única habitação para satisfazer uma expectativa de crédito especulativo, torne-se veracidade, não é permitido recuar, afinal, como já dizia o grande escritor mineiro, em Grande Sertão: Veredas, “a vida é assim (...) o que ela quer da gente é coragem.”. Não desistamos do direito que queremos!

\section{BIBLIOGRAFIA}

ALEXY, Robert. Teoria dos Direitos Fundamentais. Tradução de Virgílio Afonso da Silva da $5^{a}$ edição alemã Theorie der Grundrechte. São Paulo. Malheiros. 2ª ed. 2015.

ASSIS, Araken. Princípio da Dignidade da Pessoa Humana e Impenhorabilidade da Residência Familiar. Revista Jurídica: órgão nacional de doutrina, jurisprudência, legislação e crítica judiciária. Ano 57, n³84, OUT. 2009.

AZEVEDO, Álvaro Vilaça. Bem de Família com Comentários à Lei 8009/90. São Paulo. Atlas. 6 ed. 2010.

BARCELlOS, Ana Paula de. A Eficácia Jurídica dos Princípios Constitucionais. O Princípio da Dignidade da Pessoa Humana. São Paulo. Renovar, 2a .ed. 2008.

BARCELLONA, Pietro. La formación del jurista. Madri: Editorial Civitas, 1977.

BARROSO, Luis Roberto. O Direito Constitucional e a Efetividade de Suas Normas. Rio de Janeiro. Renovar. $4^{\text {a }}$ ed. 2000. 
BRASIL. Congresso Nacional. Lei 8.009/90, de 29 de março de 1990. Diário Oficial de União. Disponível em <http://www.planalto.gov.br/ccivil_03/leis/L8009.htm>. Acesso em 19.02.2016.

BRASIL. Superior Tribunal de Justiça. Brasília. Recurso Especial $n^{\circ}$ 1.363.368/MS. Ministro Relator Luis Felipe Salomão. Julgado em 12 de novembro de 2014. Publicado no Diário da Justiça de 21 de novembro de 2014. Disponível em: <http://www.stj.jus.br>. Acesso em 19.02.2016.

BRASIL. Supremo Tribunal Federal. Brasília. Recurso Extraordinário $n^{\circ}$ 407.688-8/SP. Ministro Relator Cézar Peluso. Julgado em 8 de fevereiro de 2006. Publicado no Diário da Justiça de 6 de outubro de 2006. Disponível em: < http://www.stf.gov.br>. Acesso em 19.02.2015.

BITTAR, Eduardo C. B. Metodologia da Pesquisa Jurídica. Teoria e Prática da Monografia para os Cursos de Direito. São Paulo. Saraiva. 1.ed. 2001.

BRANCO, Paulo Gustavo Gonet; COELHO, Inocêncio Martires; MENDES, Gilmar Ferreira. Curso de Direito Constitucional. São Paulo. Saraiva. 5a .ed. 2010.

DIMOULIS, Dimitri. Manual de Introdução ao Estudo do Direito. São Paulo. R7, $3^{\mathrm{a}}$ ed. 2010.

FACHIN, Luiz Edson. Estatuto Jurídico do Patrimônio Mínimo. Rio de Janeiro: Renovar, 2001.

FACHIN, Luiz Edson; TEPEDINO, Gustavo. Diálogos sobre direito Civil - Volume II. Rio de Janeiro. Renovar. 2008.

FARIAS, Cristiano Chaves de; ROSENVALD, Nelson. Curso de Direito Civil - Parte Geral. São Paulo. Jus Podium. $8^{\mathrm{a}}$ ed. 2008.

HORA NETO, João. O bem de família, a fiança locatícia e o direito à moradia. Revista da Esmese, Aracaju, n. 9, p. 15-56, 2006. Disponível em: $<$ http://www.esmese.com.br/revistas.htm>.

LÔBO, Paulo. A Constitucionalização do Direito Civil Brasileiro. In: TEPEDINO, Gustavo (org). Direito Civil Contemporâneo: novos problemas à luz da legalidade constitucional: anais do Congresso Internacional de Direito Civil-Constitucional da Cidade do Rio de Janeiro. São Paulo. Atlas. 2008. p.20.

SARLET, Ingo Wolfang. A Eficácia dos Direitos Fundamentais: Uma Teoria Geral dos Direitos Fundamentais na Perspectiva Constitucional. Porto Alegre. Livraria do Advogado. $10^{\mathrm{a}}$ ed. 2009.

SARLET, Ingo Wolfgang. Supremo Tribunal Federal, o Direito à Moradia e a Discussão em torno a Penhora do Imóvel do Fiador. Revista da Ajuris. V.34. n. 107. SET 2007. 


\section{RFD}

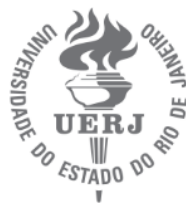

SCHEREIBER, Anderson. Direito à moradia como fundamento para a impenhorabilidade do imóvel residencial do devedor solteiro. In: RAMOS, Carmen Lucia Silveira e outros (org). Diálogos sobre Direito Civil: construindo a racionalidade contemporânea. Rio de Janeiro. Renovar. 2002.

SILVA, José Afonso da. Curso de Direito Constitucional Positivo. São Paulo. Malheiros, $32^{\mathrm{a}}$. ed. 2009.

SOUZA, Sylvio Capanema de. O Bem de Família no Novo Código Civil. CEPAD 08/2003. Editora Espaço Jurídico. Rio de Janeiro. 2003.

STABILE FILHO, José. Bem de Família e execução. Revista dos Tribunais, São Paulo, a.80, n. 669, JUL 1991.

TAVARES, André Ramos. Curso de Direito Constitucional. São Paulo. Saraiva. 2002.

TEPEDINO, Gustavo. A Nova Propriedade (O Seu Conteúdo Mínimo, entre o Código Civil, a Legislação Ordinária e a Constituição). Revista Forense, Rio de Janeiro, v.306. 1989.

TEPEDINO, Gustavo. O Direito Civil-Constitucional e suas Perspectivas Atuais. In: TEPEDINO, Gustavo (org). Direito Civil Contemporâneo: novos problemas à luz da legalidade constitucional: anais do Congresso Internacional de Direito Civil-Constitucional da Cidade do Rio de Janeiro. São Paulo. Atlas. 2008

TUCCI, José Rogério Cruz e (Coord). A penhora e o bem de família do fiador da locação. São Paulo. Editora RT. 2003.

VELOSO, Zeno. Bem de Família. Revista de Direito Civil, a.15, n.55.1991.

VEnOSA, Silvio de Salvo. Direito Civil - Direito de Família. São Paulo. Atlas. 10ª ed. 2010. 